\title{
Vplyv protipandemických opatrení na umelcov - frekventantov Doplňujúceho pedagogického štúdia v oblasti hudobného a dramatického umenia na Akadémii umení v Banskej Bystrici
}

The impact of anti-pandemic measures on artists - attenders of Additional pedagogical studies in music and dramatic art at the Academy of arts in Banská Bystrica

Mária Strenáčiková sen. / strenacikova@aku.sk

Faculty of performing arts, Academy of arts in Banská Bystrica, SK

Mária Strenáčiková jun. / mstrena@gmail.com

Faculty of performing arts, Academy of arts in Banská Bystrica, SK

\begin{abstract}
The paper focuses on the changes in the artists' lives caused by the COVID-19 related measures. It brings information from research conducted in October 2020. The sample consisted of 40 Slovak professional performers - musicians and actors, completing their Additional pedagogical studies at the Academy of Arts in Banská Bystrica. From the questionnaire and the semi-structured interviews answers, we found that the changes affected several areas in the artists' lives, especially their work activities and further their income level, mental state and leisure time. Despite numerous additional difficulties, most respondents do not intend to change their profession. Most artists described the changes as negative, although not all considered them onerous, and some respondents said that they did not feel any changes.
\end{abstract}

Key words

performing artist, pandemic, measures, impact 


\title{
Úvod
}

\section{Teoretické východiská}

\begin{abstract}
„Hudba mi pomohla k lepšiemu životu ... moja hudba pomáha l’ud’om $k$ úsmevu. Nemusi sa mi to podarit’ vždy, ale stoji mi to za to, aby som v tom pokračoval a zlepšoval sa a práve v tomto vidím svoj zmysel života."

(hudobnik, pedagóg)
\end{abstract}

Vyhlásenie mimoriadnej situácie na Slovensku a pandémie ochorenia COVID-19 dňa 11. marca 2020 malo za následok zavedenie prísnych opatrení na celom území Slovenska. V kultúrnom sektore opatrenia spôsobili, že umelci stratili možnost̉ vykonávat svoje povolanie v štandardných podmienkach: koncerty a divadelné predstavenia boli zrušené, skúšky pozastavené a dvere ich domovských inštitúcií zatvorené. Ani postupné uvolňovanie opatrení neumožnilo umelcom začat' hned' pracovat ako za bežných okolností. Koncertné sály, kiná a divadlá otvorili svoje brány až vo 4. fáze uvol'ňovania. Od 20. 5. 2020 boli povolené hromadné podujatia kultúrnej a spoločenskej povahy do 100 prítomných pri dodržiavaní rôznych opatrení, ako napr. zabezpečenie rozostupov 2 metre medzi prítomnými $^{1}$, od 3. 6. 2020 sa mohli organizovat predstavenia so šachovnicovým sedením divákov s prekrytými hornými dýchacími cestami², od 10. 6. 2020 sa povolený počet prítomných na podujatiach zvýšil na 500³, od 20. 6. 2020 otvorené prevádzky divadelných, hudobných, či filmových predstavení dodržiavali aj nad’alej rôzne opatrenia ${ }^{4}$ Od 1. 7. 2020 bolo povolené organizovanie hromadných podujatí nad 1000 osôb, pričom kapacita priestorov pre sediace obecenstvo musela ostat' na $50 \%$ nevyužitá 5 . Od 7. 7. 2020 sa mohli organizovat podujatia nad 1000 účastníkov, pričom šachovnicové sedenie sa nahradilo sedením divákov v každom druhom rade. Obsadenie kapacity priestorov bolo limitované na do $50 \%{ }^{6}$ Aj po takmer štyroch dlhých mesiacoch ostalo povolené využitie kapacity len $50 \%$. Navyše v čase letných mesiacov majú mnohé kultúrne inštitúcie „prázdniny“, a preto zostali viacerí umelci bez možnosti reálneho vystupovania, ak si neorganizovali koncerty a predstavenia sami, alebo ak sa neprezentovali v rámci rôznych festivalov, workshopov alebo iných letných akcií.

Niekol'ko týždňov po nástupe do zamestnania (august / september 2020) sa situácia začala opät komplikovat’ a nastúpila druhá vlna pandémie, ktorá priniesla d’alšie obmedzenia a v konečnom dôsledku aj opätovné zatváranie kultúrnych a umeleckých inštitú-

1 Opatrenie Úrad verejného zdravotníctva Slovenskej republiky (d’alej ÚVZ SR) pri ohrození verejného zdravia OLP/4085/2020, 19. 05. 2020.

2 Opatrenie ÚVZ SR pri ohrození verejného zdravia, OLP/4592/2020, 02. 06. 2020.

3 Opatrenie ÚVZ SR pri ohrození verejného zdravia, OLP/4738/2020, 09. 06. 2020.

4 Opatrenie ÚVZ SR pri ohrození verejného zdravia, OLP/5091/2020, 19. 06. 2020.

5 Opatrenie ÚVZ SR pri ohrození verejného zdravia, OLP/5274/2020, 25. 06. 2020.

6 Opatrenie ÚVZ SR pri ohrození verejného zdravia, OLP/5454/2020, 03. 07. 2020. 
cií. Od 18.9.2020 boli zakázané hromadné podujatia v exteriéri nad 1000 osôb, v interiéri nad 500 osôb a v prevádzkach verejného stravovania dokonca úplne (s istými výnimkami $)^{7}$. Od 15.10.2020 boli povolené len podujatia, ktorých zúčastnení nepresiahli počet 6 osôb. Pre organizáciu podujatia s väčším počtom účastníkov platili prísne pravidlá8.

Jesenná snaha vrátił život umelcov do štandardných kol’ají bola zastavená a 24. 10. 2020 začal na Slovensku platit’ zákaz vychádzania ${ }^{9}$, čo výrazne obmedzilo možnost̉ sebarealizácie umelcov, ich vystúpenia na verejnosti, štúdium a nácvik nových diel v skupinách, rovnako ako participáciu na „živých“ umeleckých podujatiach, workshopoch, sútažiach a konferenciách. Niektorí flexibilní umelci sa rýchle prispôsobili a preorientovali sa na performanciu v online prostredí. Začali zdielat online vystúpenia a „obývačkové koncerty“ na svojich webových stránkach (fanpage), Instagramových profiloch, na Facebooku, či YouTube. Online streamy boli dostupné prevažne bez poplatkov, a preto umelci v niektorých prípadoch nemali žiadny príjem. Ďalšou aktivitou umelcov, prostredníctvom ktorej sa chceli priblížit svojim poslucháčom boli koncerty na sídliskách. Niektoré z nich odvysielala RTVS.

Na novú situáciu reagovali aj umelecké inštitúcie. Slovenská filharmónia promptne pripravila Koncerty bez publika v online priestore s týždennou periodicitou. Pre školákov zriadila na web-stránke sekciu Filharmonická škôlka, v ktorej predstavila koncerty primerané veku detského poslucháča a pre pedagógov sekciu Hudobná akadémia s dielami vhodnými na edukačné účely. Slovenské národné divadlo na svojej stránke sprístupnilo sekciu SND Doma, v rámci ktorej bolo možné sledovat kvantum epizód v subsekciách ako Rozprávky s činohrou, Maturita s činohrou, Káva s činohrou, Malá denná hudba atd'. V októbri sa uskutočnila prvá on-line premiéra v jeho histórii.

V zahraničí bola situácia podobná. Dramatický dosah opatrení na umelcov dokumentuje napr. fakt, že v USA ostalo v máji 2020 až 27,4 \% performančných umelcov nezamestnaných ${ }^{10}$.

I ked' niektoré aktivity sa umelcom podarilo preniest’ do virtuálneho prostredia, dlhodobo trvajúca situácia prinášajúca širokú paletu rôznych obmedzení nevyhnutne vyústila do limitovania ich príjmov a následne sa odzrkadlila na zmenách v ekonomike ich domácností. Uvedené zmeny negatívne pôsobia aj na psychiku umelcov, čo môže spätne negatívne ovplyvnit ich budúce umelecké výkony. Dosah protipandemických opatrení na život umelcov nie je zmapovaný, a preto sme sa rozhodli zrealizovat’ výskumnú sondu, pomocou ktorej by sme nahliadli do uvedenej problematiky.

7 Opatrenie ÚVZ SR pri ohrození verejného zdravia, OLP/7311/2020, 17. 09. 2020.

8 Opatrenie ÚVZ SR pri ohrození verejného zdravia, OLP/8326/2020, 14. 10. 2020.

9 Uznesenie vlády SR č. 678/2020. Bod A.2.

10 MARRONE, James V., RESETAR, Susan A., SCHWAM, Daniel. 2020. The Pandemic Is a Disaster for Artists [online]. 2020, 4. august. [cit. 2020-11-05]. Dostupné z: https://www.rand.org/blog/2020/07/the-pandemicis-a-disaster-for-artists.html. 


\section{Výskumná vzorka a metódy skúmania}

Vo výskumnej sonde, ktorej cielom bolo popísat najvýraznejšie zmeny, ktoré nastali pod vplyvom protipandemických opatrení u profesionálnych umelcov - frekventantov Doplňujúceho pedagogického štúdia (d’alej DPŠ) so zameraním na hudobnú a dramatickú interpretáciu na Akadémii umení v Banskej Bystrici, sme si stanovili dve výskumné otázky. VO1: Aký vplyv majú protipandemické opatrenia na pracovnú sféru a príjmy umelcov frekventantov DPŠ so zameraním na hudobnú a dramatickú interpretáciu na Akadémii umení v Banskej Bystrici?

VO2: Aký vplyv majú protipandemické opatrenia na volnočasové aktivity umelcov frekventantov DPŠ so zameraním na hudobnú a dramatickú interpretáciu na Akadémii umení v Banskej Bystrici?

\subsection{Charakteristika výskumnej vzorky}

Na získanie dát sme oslovili profesionálnych umelcov - hudobníkov, hercov a režisérov. Všetci respondenti si dopíňajú pedagogické vzdelanie v rámci DPŠ na Akadémii umení v Banskej Bystrici. V dalšom texte budeme na reprezentáciu subjektov vzorky a ich názorov používat pojem „umelci“, resp. respondenti, opýtaní. Výskumný súbor tvorilo 40 subjektov, z toho 22 žien a 18 mužov. Vek respondentov sa pohyboval v rozmedzí 20-52 rokov, pričom vekový priemer bol 32,28 roka a medián 32 rokov.

Respondenti pôsobia v rôznych umeleckých a kultúrnych inštitúciách, ako je činoherné divadlo, bábkové divadlo, opera, orchester, filharmónia a amatérsky súbor, alebo vykonávajú povolanie slobodného umelca (nemajú status zamestnanca v žiadnej inštitúcii). Z geografického hladiska ide o zástupcov západoslovenského (16), stredoslovenského (13) i východoslovenského regiónu (11).

Z hladiska zastúpenia umeleckých povolaní vzorku tvorili herci, dramaturgovia a režiséri, hráči na hudobnom nástroji, speváci a skladatelia.

Zastúpenie jednotlivých umeleckých povolaní vo vzorke herec; $15 ; 38 \%$

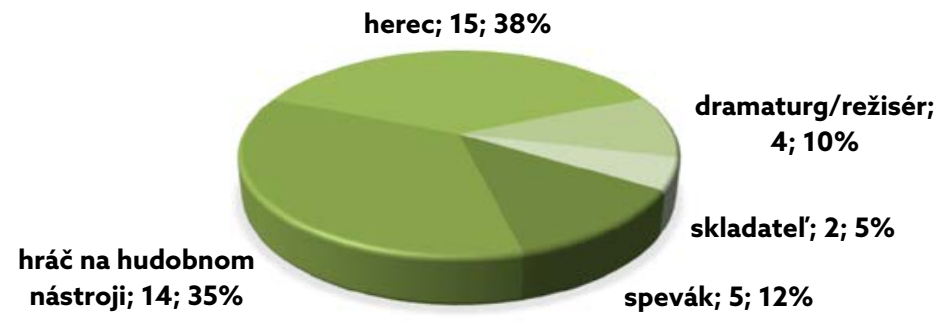

Graf 1 Zastúpenie jednotlivých umeleckých povolaní vo vzorke; zdroj: vlastný. 


\subsection{Metódy skúmania}

Dáta sme získavali pomocou pološtruktúrovaných rozhovorov a dotazníkov. Rozhovory sme realizovali on-line formou cez platformu Google Meet v mesiacoch september-október 2020. Otázky v rozhovore boli zamerané na zmapovanie zmien v životoch umelcov v dôsledku protipandemických opatrení. Dotazníky boli neštandardizované s uzavretými, polouzavretými i otvorenými položkami. Vytvorili sme ich pomocou Google Forms a zverejnili na internete (študentom DPŠ sme poslali link). Dotazníky boli dostupné od 11. 10. 2020 do 18. 10. 2020. Koncept internej a externej validity, resp. opakovatelnosti a objektivity sme nahradili konceptmi dôveryhodnosti (postup sme konzultovali s odborníkom, ktorý sa priamo nezúčastnil na výskume) a hodnovernosti (aplikovali sme čiastočnú trianguláciu metód - okrem analýzy rozhovorov sme ako zdroj informácií využili aj odpovede v dotazníkoch). Naša prítomnost̉ nemohla ovplyvnit získané dáta, preto reaktivitu nepovažujeme za riziko ohrozujúce validitu. Zároveň sme zdôrazňovali možnost̉ odmietnutia odpovede, resp. pokračovania v rozhovore. Obsahovú validitu a reliabilitu nástrojov sme sa snažili zabezpečit aj viacnásobným posudzovaním expertov. Pilotné odskúšanie nástrojov prebehlo v septembri 2020. Tri otázky sme upravili tak, aby boli zrozumitelnejšie.

Pri spracovaní získaných dát sme používali program Excel a Atlas.ti 8. Dáta sme analyzovali po kvantitatívnej stránke (deskriptívna štatistika) i po kvalitatívnej. Kvalitatívna analýza zahńňala okrem analýzy odpovedí aj transkripciu, segmentáciu, kódovanie, poznámkovanie, grafické zobrazovanie a vytváranie štruktúr.

\section{Výsledky a diskusia}

\subsection{Pracovné aktivity ako zdroje príjmov umelcov}

Najprv sme sa zamerali na hlavný zdroj príjmov respondentov. Zistili sme, že napriek umeleckej činnosti každého z nich, u 38 \% je vyučovanie aktuálne dominujúcim zdrojom príjmov. $5 \%$ respondentov uviedlo ako rovnocenný hlavný zdroj príjmov pedagogickú aj umeleckú činnost', $20 \%$ divadlo, film, televíziu alebo rozhlas, $10 \%$ operu, orchester alebo filharmóniu a u 7,5\% zabezpečuje finančný chod domácnosti partner. Až $20 \%$ opýtaných uviedlo iný hlavný zdroj príjmov, ako napr. grant s honorármi, štipendium v rámci doktorandského štúdia, či prácu v „neumeleckom“ odvetví, pričom len u $5 \%$ respondentov sme zaznamenali dominujúci príjem z práce nesúvisiacej s umením (pedagogické pôsobenie spájame s umením, nakolko ide o vzdelávanie v oblasti umenia na rôznych stupňoch škôl). 


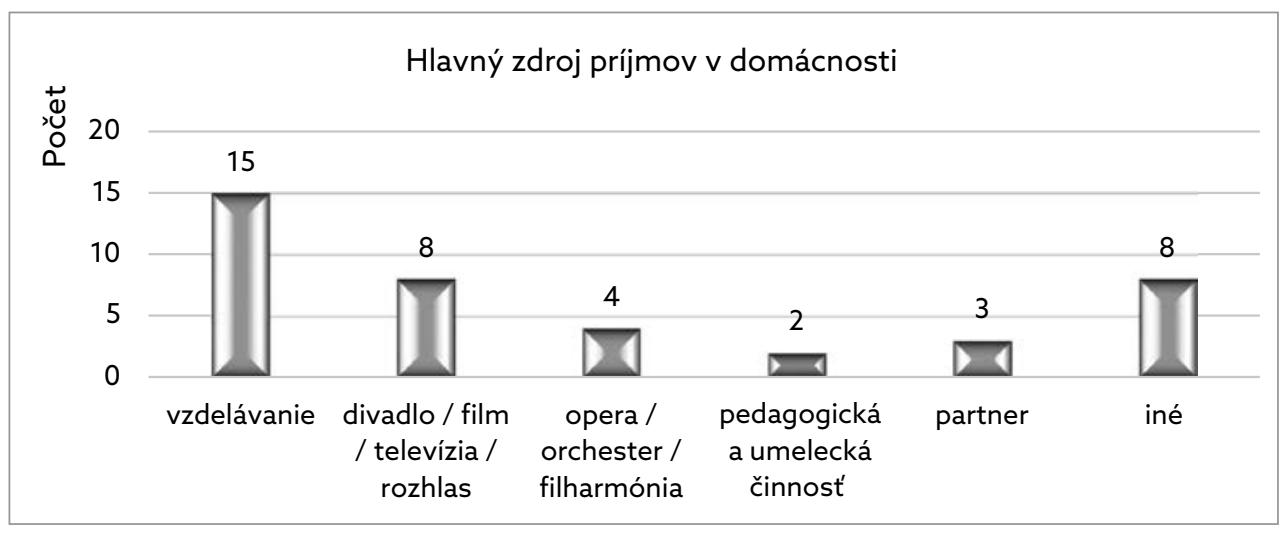

Graf 2 Hlavný zdroj príjmov v domácnostiach umelcov; zdroj: vlastný.

Ďalej nás zaujímalo, či majú umelci aj iné zdroje príjmov okrem tých, ktoré uviedli ako hlavné. Dvaja na danú otázku neodpovedali, $35 \%$ sa vyjadrilo, že iné zdroje príjmov momentálne nemá a až 57,5\% uviedlo, že k ich príjmom patrí pedagogická činnost ( 15 z nich však považuje v súčasnej situácii príjem z vyučovania za hlavný). Medzi inými umeleckými príjmami figuroval okrem vzdelávania napríklad aj dabing, práca v rozhlase, vo filme a reklame, či práca na pozíciách hudobného redaktora, zdravotného klauna, režiséra na vol’nej nohe, tanečníka. (Jeden respondent začal písat a predávat knihy a jeden mal'ovat’ a predávat’ obrazy, čo tiež považujeme za umeleckú aktivitu.) 12,5 \% spomenulo mimoumelecké aktivity, ako je animátorstvo, práca asistenta v sprostredkovatel’skej firme, správa webových stránok a sociálnej siete, realizácia inventúr a 2,5\% uviedlo dobrovol'nícke činnosti (asistent trénera, vol’nočasové športové aktivity).

\section{Doplňujúce zdroje prijmov umelcov [\%]}

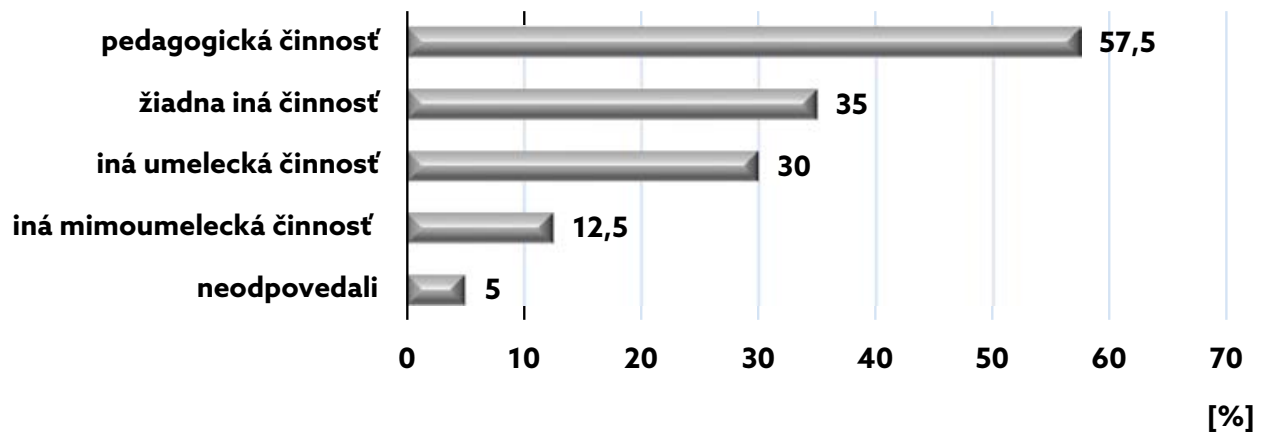

Graf 3 Percentuálne zastúpenie doplňujúcich príjmov umelcov; zdroj: vlastný. 


\subsubsection{Vplyv protipandemických opatrení na prácu umelcov}

Pri mapovaní dôsledkov protipandemických opatrení sme nechali umelcom volný priestor na vyjadrenie vlastných myšlienok. Najčastejšie skloňovali slová príjem, zrušenie, opatrenia, divadlo... Väčšinou išlo o negatívny kontext, len dvaja respondenti spomenuli pozitívne dôsledky opatrení, dvaja žiadne a dvaja mierne.

Tab. 1 Dôsledky protipandemických opatrení na respondentov; zdroj: vlastný.

\begin{tabular}{|l|l|l|}
\hline $\begin{array}{l}\text { Dôsledky } \\
\text { opatrení }\end{array}$ & $\begin{array}{l}\text { Počet } \\
\text { umelcov }\end{array}$ & Príklady vyjadrení \\
\hline Negatívne & $85 \%$ & "Dôsledky? Negatívne, samozrejme." \\
\hline Pozitívne & $5 \%$ & $\begin{array}{l}\text { "... pozitívne - v tom zmysle, že sme neučili, a tak som mal viac času na rodi- } \\
\text { nu, stavbu (ked'že prerábame) a aj viac kl'udu na komponovanie - resp. aran- } \\
\text { žovanie..." }\end{array}$ \\
\hline Mierne & $5 \%$ & $\begin{array}{l}\text { "Rušenie koncertov a hudobných vystúpení ma zatial' zasiahlo vcelku mier- } \\
\text { ne, ked'že som platený zo štátneho rozpočtu a na tento rok by mali byt' ešte } \\
\text { finančné prostriedky ako v [názov inštitúcie], tak v škole." }\end{array}$ \\
\hline Žiadne & $5 \%$ & "Mňa to neovplyvnilo, nakol'ko som na TPP11." \\
\hline
\end{tabular}

Ďalej sme sa zamerali na vplyvy protipandemických opatrení na prácu umelcov. Zistili sme, že až 67 \% umelcov sa v súvislosti so zavedením opatrení vyjadrovalo k obmedzeniu ich umeleckých pracovných aktivít: išlo o zrušenie predstavení $(9 \times)$, koncertov $(9 \times)$, akcií a svadieb $(6 \times)$, projektov $(4 \times)$, festivalov $(4 \times)$, inscenácií $(2 \times)$, zájazdov (2×), dabingov $(1 \times)$ a pod. $10 \%$ respondentov sa zmienilo o problémoch s vyučovaním v online prostredí, $5 \%$ o možnosti realizovat nové aktivity a 2,5\% o novom zamestnaní.

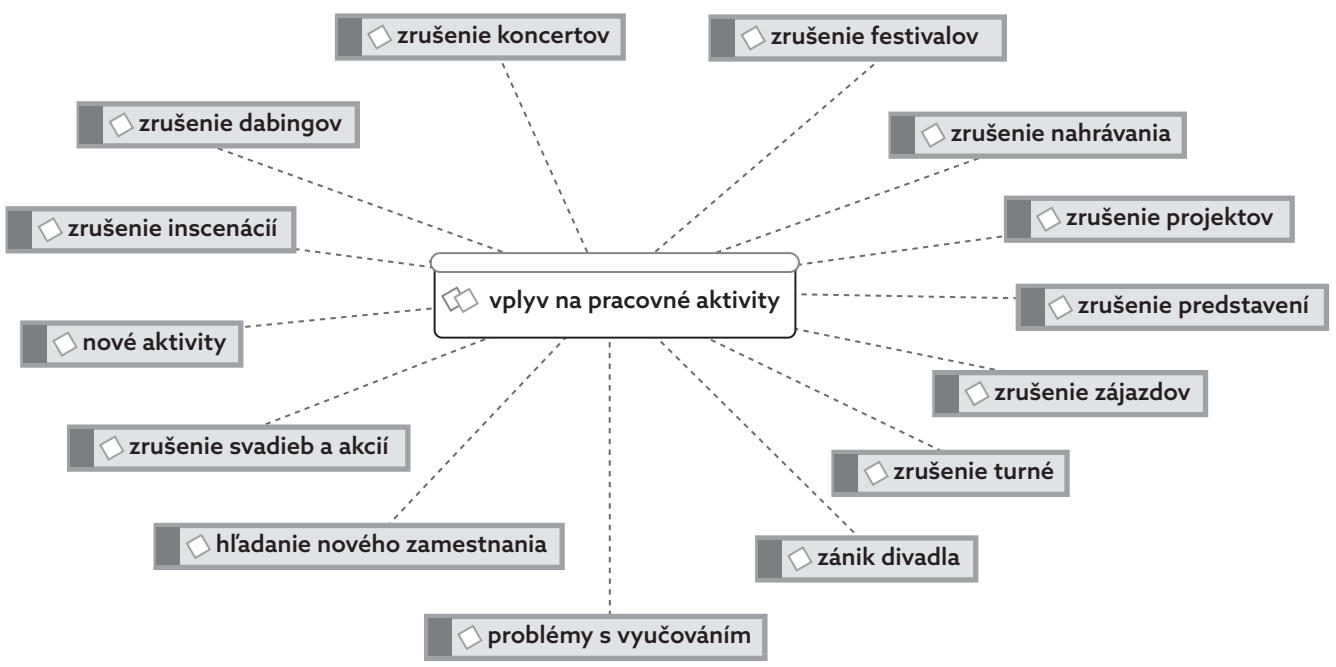

Obr. 1 Vplyv protipandemických opatrení na pracovné aktivity umelcov; zdroj: vlastný.

11 trvalý pracovný pomer 
Negatívnym dôsledkom zrušenia predstavení a zatvorenia divadiel a koncertných sál na umelcov by mohla byt stagnujúca úroveň ich umeleckých schopností, pre ktorých rozvoj nie je pri reštrikčných opatreniach vhodný priestor. Práca umelca si vyžaduje neustálu prípravu, zdokonalovanie, cvičenie, nacvičovanie, skúšanie, a preto sociálny dištanc a s ním spojené nariadenia vnímajú umelci ako dôvody úpadku kvality svojich zručností a schopností (17,5\%), prípadne ich stagnovania (12,5\%).

Tab. 2 Dôsledky opatrení na umelecké schopnosti respondentov; zdroj: vlastný.

\begin{tabular}{|l|l|l|}
\hline Dôsledky opatrení & Počet umelcov & Príklady vyjadrení \\
\hline $\begin{array}{l}\text { Úpadok kvality } \\
\text { schopností }\end{array}$ & $17,5 \%$ & $\begin{array}{l}\text { "Samozrejme okrem toho, že nás to (rušenie koncertov) pri- } \\
\text { pravilo o finančný príjem, ako herci herecky upadáme.” } \\
\text { "Zrušenie koncertov ... Znížilo to našu kvalitu, ked'že sme prišli } \\
\text { o všetku prax a dokonca aj o skúšky." }\end{array}$ \\
\hline Stagnácia schopností & $12,5 \%$ & "...naša práca stagnuje a nevyvíjame sa d'alej.” \\
\hline
\end{tabular}

\subsubsection{Zmeny v ekonomike domácností}

Samostatnú oblast̉ našej výskumnej sondy tvorili zmeny v ekonomike domácností umelcov - frekventantov DPŠ na Akadémii umení v Banskej Bystrici. Zaujímalo nás, ako sa zmenili príjmy a výdavky týchto ekonomických jednotiek, či sa protipandemické opatrenia odzrkadlili na finančných rezervách a na výdavkoch ich domácností.

\section{Príjmy}

Respondenti sa vyjadrovali prevažne k viac alebo menej zmeneným celkovým príjmom v negatívnej rovine a prejavili nespokojnost’ s obmedzenými a absentujúcimi príjmami. Ked’že celkový príjem respondentov je tvorený viacerými zložkami, zaznamenali sme vysokú variabilitu ich odpovedí. V̌setci majú za štandardných okolností príjem z umeleckej činnosti (UČ), 57,5 \% má príjmy aj z pedagogickej činnosti a 12,5\% z mimoumeleckej činnosti. Až $15 \%$ respondentov nepocítilo žiadnu zmenu (u viacerých to bolo spôsobené

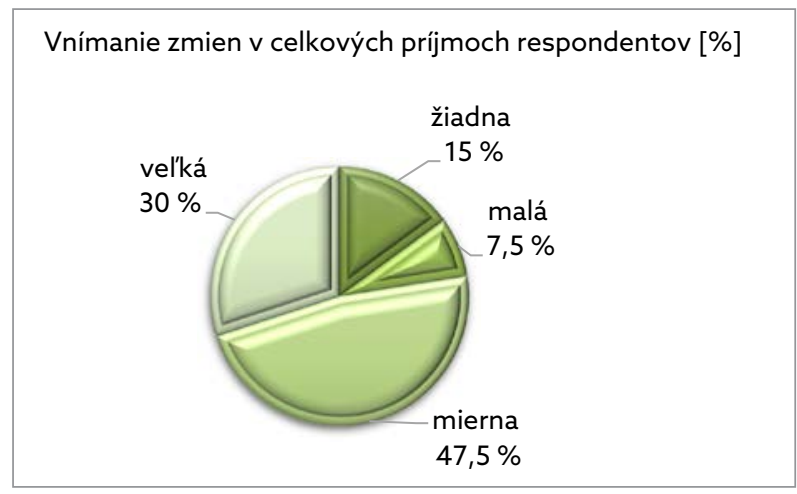

Graf 4 Vnímanie zmien v celkových príjmoch respondentov [ \%]; zdroj: vlastný. 
d’alším príjmom v inom zamestnaní, či príjmom partnera). $30 \%$ označilo zmeny za vel'mi vel'ké. U 47,5 \% sme zaevidovali vnímanie len miernych a u 7,5\% malých zmien, ktoré sa takmer výlučne spájali s udržaním príjmu z pedagogickej činnosti.

Tab. 3 Dôsledky opatrení na celkové príjmy respondentov; zdroj: vlastný.

\begin{tabular}{|c|c|c|}
\hline $\begin{array}{l}\text { Dôsledky } \\
\text { opatrení }\end{array}$ & $\begin{array}{l}\text { Počet } \\
\text { umelcov }\end{array}$ & Príklady vyjadrení \\
\hline $\begin{array}{l}\text { Vel'ká } \\
\text { zmena }\end{array}$ & $30 \%$ & $\begin{array}{l}\text { "... som prišla o } 70 \text { \% príjmu." } \\
\text { "Prišli sme o väčsinu prijmov." } \\
\text { "Príjem mi tvorí jedine [názov školy], kde však ... mám len } 35 \text { \% úväzok, } \\
\text { takže je to vel'mi chabé." } \\
\text { "Ostal mi iba príjem zo školy, ktorý je absolútne nedostačujúci." } \\
\text { "... z celkového príjmu mi financie klesli v priemere o } 50-60 \% \text { "My sme sa zbalili a odišli na niekol'ko mesiacov na chatu ... Žili sme bez } \\
\text { príjmu - z našetrených peňazí." }\end{array}$ \\
\hline $\begin{array}{l}\text { Mierna } \\
\text { zmena }\end{array}$ & $47,5 \%$ & $\begin{array}{l}\text { "Ekonomické zázemie to ovplyvnilo, to samozrejme, ale na druhej strane } \\
\text { ma zachránila práca v [názov školy], kde mi išiel pravidelný príjem." }\end{array}$ \\
\hline $\begin{array}{l}\text { Malá } \\
\text { zmena }\end{array}$ & $7,5 \%$ & $\begin{array}{l}\text { "Nakol'ko mojim hlavným zdrojom prijmu je školstvo, zásadným spôsobom } \\
\text { sa ma to nedotklo..." }\end{array}$ \\
\hline $\begin{array}{l}\text { Žiadna } \\
\text { zmena }\end{array}$ & $15 \%$ & $\begin{array}{l}\text { „....mňa osobne to nejak neovplyvnilo, čo sa týka financií. Naša [škola], } \\
\text { ked'že vyučovala online ... dostávali sme výplatu normálne." }\end{array}$ \\
\hline
\end{tabular}

Malé a mierne zmeny v príjmoch respondenti spájali so znížením príjmov (strata pohyblivej zložky príjmu alebo fixné zníženie platu pri zachovaní iného príjmu) a vel'ké zmeny s úplnou stratou príjmov.

Okrem celkových príjmov sme sa zamerali aj na zmeny v príjme z umeleckej činnosti (UČ) respondentov. Polovica opýtaných spomenula zníženie príjmov z UČ alebo ich úplnú absenciu v čase pandémie. Jeden respondent sa vyjadril, že pocítil miernu zmenu v danej oblasti a jeden uviedol, že uňho k žiadnej zmene v zmysle znižovania príjmu z UČ nedošlo.

Tab. 4 Dôsledky opatrení na prijmy respondentov z umeleckej činnosti (UČ); zdroj: vlastný.

\begin{tabular}{|c|c|c|}
\hline $\begin{array}{l}\text { Dôsledky } \\
\text { opatrení }\end{array}$ & $\begin{array}{l}\text { Počet } \\
\text { umelcov }\end{array}$ & Príklady vyjadrení \\
\hline $\begin{array}{l}\text { Zníženie } \\
\text { príjmov } \\
\text { z UČ }\end{array}$ & $35 \%$ & $\begin{array}{l}\text { "Znižovala sa mzda na } 80 \% \text {. A z dôvodu opatrení sa zrušili aj spoločenské } \\
\text { akcie, ktoré som už spomínal, a tým aj ,bočné príjmy." } \\
\text { "'...absencia hraní na festivaloch a koncertoch bola citel'ná ... vinou pandé- } \\
\text { mie odpadol príjem okolo } 400 \text { až } 600 \text { EUR (mesačne)." }\end{array}$ \\
\hline $\begin{array}{l}\text { Úplná ab- } \\
\text { sencia príj- } \\
\text { mov z UČ }\end{array}$ & $15 \%$ & $\begin{array}{l}\text { "Príjmy z nezávislej činnosti, SZČO - slobodného povolania - umelec, boli } \\
\text { vobdobí karantény na 0." } \\
\text { "Tie (predstavenia) sa samozrejme všetky zrušili, a tým aj väčšina môjho } \\
\text { príjmu. Samozrejme odišli aj iné možnosti ako si privyrobit', akými sú na- } \\
\text { táčanie, nahrávanie atd'." } \\
\text { "Vypadli mi príjmy z troch skúšobných procesov (cca } 8000 \text { eur)." }\end{array}$ \\
\hline $\begin{array}{l}\text { Mierna } \\
\text { zmena }\end{array}$ & $2,5 \%$ & "Naštastie sme to nepocítili nijako výrazne." \\
\hline $\begin{array}{l}\text { Žiadna } \\
\text { zmena }\end{array}$ & $2,5 \%$ & $\begin{array}{l}\text { "V divadle sa šili rúška pre VUC }{ }^{12} \text {, ked'že ako divadlo pod nich spadáme. } \\
\text { Na platy nám vtedy nesiahli." }\end{array}$ \\
\hline
\end{tabular}

12 vyšší územný celok 


\section{Opatrenia}

Na znížené a obmedzené príjmy niektorí umelci reagovali zvýšeným šetrením (10 \%). Išlo o limitovanie nákladov na cestovanie, odloženie výdavkov na prestavbu, posun v plánovaní rodiny a pod. $\mathrm{V}$ niektorých prípadoch tažisko starostlivosti o chod domácnosti ostalo na partnerovi $(7,5 \%)$ a vo viacerých domácnostiach boli ich členovia nútení siahat do svojich rezerv (20\%). Jeden respondent sa vyjadril, že využil možnost’ podpory zo strany štátu.

Tab. 5 Opatrenia respondentov ako odpoved' na zmeny v príjmoch; zdroj: vlastný.

\begin{tabular}{|c|c|c|}
\hline $\begin{array}{l}\text { Dôsledky } \\
\text { opatrení }\end{array}$ & $\begin{array}{l}\text { Počet } \\
\text { umelcov }\end{array}$ & Príklady vyjadrení \\
\hline $\begin{array}{l}\text { Zvýšené šet- } \\
\text { renie }\end{array}$ & $10 \%$ & $\begin{array}{l}\text { "Začali sme ale obidvaja viacej šetrit', lebo sme nevedeli čo bude d'alší me- } \\
\text { siac." } \\
\text { „... nemôžeme tol'ko cestovat', musíme šetrit.". }\end{array}$ \\
\hline $\begin{array}{l}\text { Presun fi- } \\
\text { nančného } \\
\text { zabezpečenia } \\
\text { na partnera }\end{array}$ & $7,5 \%$ & $\begin{array}{l}\text { "Momentálne však ekonomické zázemie zabezpečuje manžel, ktorý nepra- } \\
\text { cuje v kultúrnej oblasti." } \\
\text { "....som na rodičovskej dovolenke a manžel má aspoň jeden zo svojich prij- } \\
\text { mov." }\end{array}$ \\
\hline $\begin{array}{l}\text { Využívanie } \\
\text { finančných } \\
\text { rezerv }\end{array}$ & $20 \%$ & $\begin{array}{l}\text { "7 mesiacov - od marca doteraz žijem z úspor a z honorárov, ktoré mi } \\
\text { prišli za prácu, ktorú som stihla urobit' do marca } 2020 . " \\
\text { "...bolo nutné siahnut' po ušetrených peniazoch určených do budúcnosti } \\
\text { (dom, diet'a, cestovanie...)." } \\
\text { "Máme našetrenú finančnú rezervu, vd'aka ktorej nepocitujeme zatial' } \\
\text { nijaké dôsledky." }\end{array}$ \\
\hline $\begin{array}{l}\text { Využitie pod- } \\
\text { pory „zvonku“ }\end{array}$ & $2,5 \%$ & $\begin{array}{l}\text { "Ako SZČO' }{ }^{13} \text { som dostala } 2 x \text { jednorázový príspevok od štátu a boli mi } \\
\text { odpustené odvody do sociálnej poistovne, rovnako tak aj do zdravotnej } \\
\text { poist'ovne. Jednalo sa však o opatrenia v ČR." }\end{array}$ \\
\hline
\end{tabular}

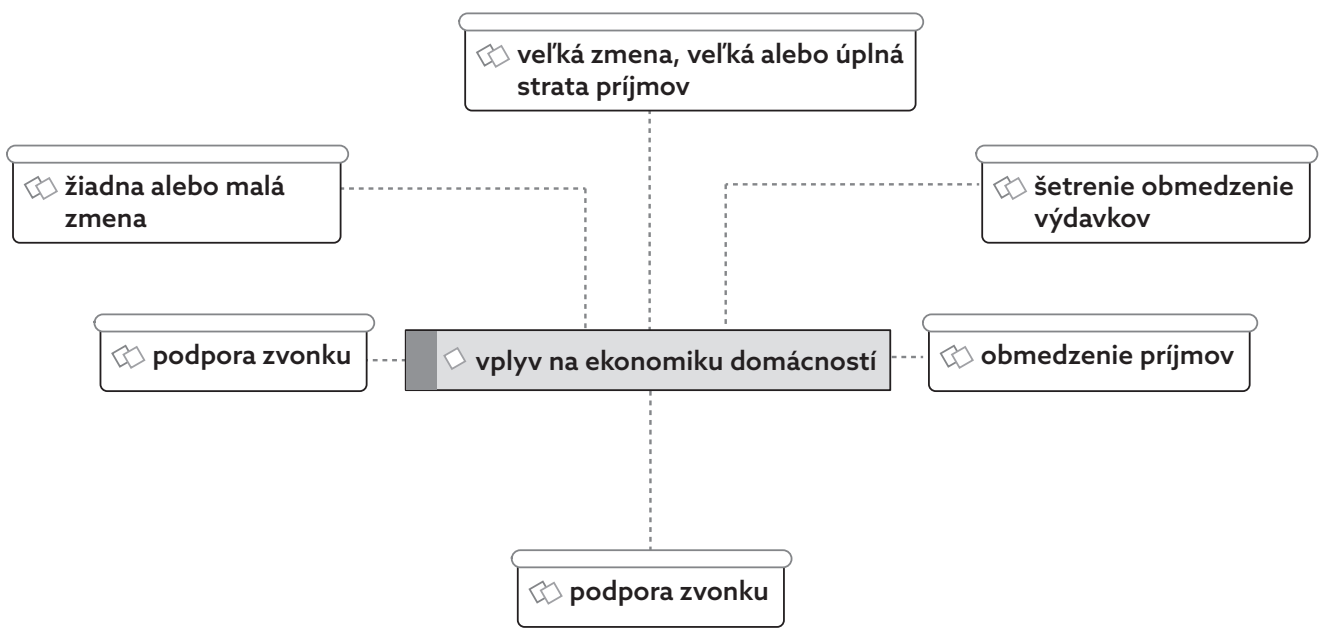

Obr. 2 Vplyv protipandemických opatrení na ekonomiku domácnosti umelcov; zdroj: vlastný.

13 samostatne zárobkovo činná osoba 


\section{Výdavky}

Čo sa týka výšky výdavkov, väčšina umelcov ich v dôsledku pandémie neznižovala. Výnimku tvorili 4 respondenti, ktorí začali šetrit (aby si zabezpečili živobytie v prípade, že situácia potrvá dlhšie), 3 respondenti, ktorí spomenuli obmedzenie cestovania a jeden umelec, ktorý referoval o vel'mi vážnych obmedzeniach - zmene životného štýlu a dokonca i rozhodnutí ohladom rozširovania vlastnej rodiny.

Tab. 6 Zmeny vo výdavkoch respondentov; zdroj: vlastný.

\begin{tabular}{|l|l|l|}
\hline $\begin{array}{l}\text { Dôsledky } \\
\text { opatrení }\end{array}$ & $\begin{array}{l}\text { Počet } \\
\text { umelcov }\end{array}$ & Príklady vyjadrení \\
\hline Žiadna zmena & $80 \%$ & $\begin{array}{l}\text { „...výdavky sa u nás nezmenili - kupujeme to, čo aj predtým a účty pla- } \\
\text { tíme rovnako." }\end{array}$ \\
\hline Šetrenie & $10 \%$ & "Ešte stále sme nevyrovnali rozdiel minutých a našetrených peňazí." \\
\hline $\begin{array}{l}\text { Obmedzenie } \\
\text { cestovania }\end{array}$ & $7,5 \%$ & $\begin{array}{l}\text { "Nakol'ko opatrenia zamedzili do značnej miery aj pohyb a cestovanie, } \\
\text { finančná situácia nebola až tak zlá, ked'že znižené výdaje na cestovanie } \\
\text { vykompenzovali znížený príjem." }\end{array}$ \\
\hline $\begin{array}{l}\text { Radikálna } \\
\text { zmena }\end{array}$ & $2,5 \%$ & $\begin{array}{l}\text { "Vzhl'adom na to, že výdavky zostali viac-menej rovnaké a príjmy malé, } \\
\text { museli sme určit' priority (čo sa budú platit’ a čo nie). Zároveň sme zme- } \\
\text { nili náš životný štýl a zrušili všetky plány, vrátane d'alšieho diet'at'a." }\end{array}$ \\
\hline
\end{tabular}

\subsection{Vplyv opatrení na psychický stav umelcov}

„Keby Vám zviazali ruky a nohy a povedali: „Kráčaj, skáč a veselo tancuj!“, ako by ste sa asi cítili? Asi tak sa cíti herec, ked' mu zatvoria divadlá a neumožnia mu hrat' pred divákmi. “

(herec, pedagóg)

Na margo protipandemických opatrení považujeme za nevyhnutné poznamenat', že okrem vplyvu na pracovné aktivity a následne finančné zabezpečenie umelcov sa pandémia podpísala aj pod negatívne zmeny v ich psychickom stave (32,5\%). Najčastejšie išlo o stratu istoty $(12,5 \%)$ a frustráciu (5\%). Okrem toho umelci spomínali sklamanie, pocitovanie psychického tlaku a celkové znižovanie motivácie, čo môže mat negatívny dosah na ich umelecké výkony po opätovnom nástupe do práce.

Tab. 7 Dôsledky opatrení na psychiku respondentov; zdroj: vlastný.

\begin{tabular}{|l|l|l|}
\hline $\begin{array}{l}\text { Dôsledky } \\
\text { opatrení }\end{array}$ & $\begin{array}{l}\text { Počet } \\
\text { umelcov }\end{array}$ & Príklady vyjadrení \\
\hline $\begin{array}{l}\text { Pocity neis- } \\
\text { toty }\end{array}$ & $32,5 \%$ & $\begin{array}{l}\text { "...v marci so mnou odmietli ... podpísat' zmluvu napriek tomu, že sme } \\
\text { boli na spolupráci takmer rok dohodnutí... Nikto doteraz nevie povedat, } \\
\text { čo sa bude diat." }\end{array}$ \\
\hline $\begin{array}{l}\text { Obavy, } \\
\text { strach }\end{array}$ & $15 \%$ & $\begin{array}{l}\text { "... Zhoršujú sa medzil'udské vzt'ahy a narastajú obavy." } \\
\text { "neviem, čo bude d'alej... bojím sa, že to bude trvat' ešte dlho...." }\end{array}$ \\
\hline $\begin{array}{l}\text { Zníženie } \\
\text { motivácie }\end{array}$ & $15 \%$ & $\begin{array}{l}\text { "... odzrkadlilo sa to na príjmoch a aj na psychickej stránke - pomaly sa vy- } \\
\text { tráca motivácia na sebe pracovat.." }\end{array}$ \\
\hline
\end{tabular}




\begin{tabular}{|l|l|l|}
\hline $\begin{array}{l}\text { Dôsledky } \\
\text { opatrení }\end{array}$ & $\begin{array}{l}\text { Počet } \\
\text { umelcov }\end{array}$ & Príklady vyjadrení \\
\hline Sklamanie & $7,5 \%$ & $\begin{array}{l}\text { „... zrušili sa hromadné akcie, koncerty, svadby, a tým pádom som bola } \\
\text { donútená nerobit' to, čo ma baví." } \\
\text { "Naivne sme verili, že sa všetko vráti do starých kol'ají..." }\end{array}$ \\
\hline $\begin{array}{l}\text { Nedostatok } \\
\text { sociálneho } \\
\text { kontaktu }\end{array}$ & $7,5 \%$ & $\begin{array}{l}\text { "Značný pokles je v komunikácii a socializácii...." } \\
\text { "Chýbajú mi osobné stretnutia, rada by som išla s niekým na kávu alebo } \\
\text { hoci aj na skúšku orchestra..." }\end{array}$ \\
\hline Frustrácia & $5 \%$ & $\begin{array}{l}\text { "...osobne pocitujem frustráciu a neistotu... táto situácia značne ovplyv- } \\
\text { nila môj rozbeh a hlavne vnútorný stav. Ved' vieme všetci... čoho sa člo- } \\
\text { vek musí vzdat', aby uspel.... }\end{array}$ \\
\hline
\end{tabular}

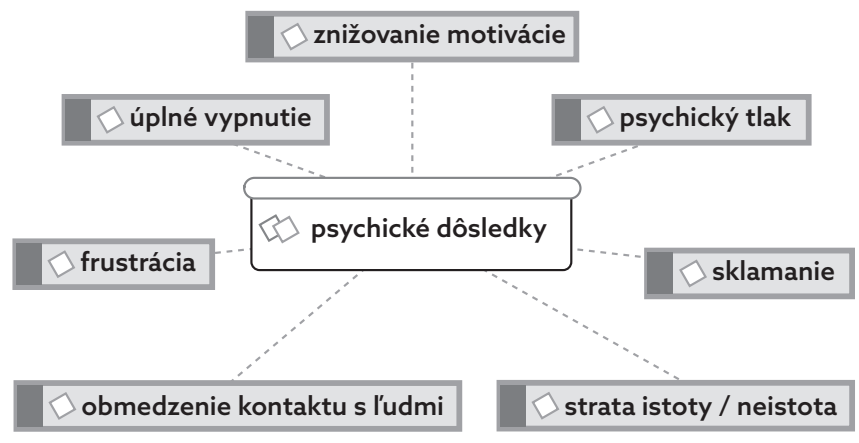

Obr. 3 Psychické dôsledky protipandemických opatrení na umelcov; zdroj: vlastný.

\subsection{Vplyv protipandemických opatrení na trávenie času umelcov}

Trávenie vol’ného času patrí k základným l’udským aktivitám, ktoré využívajú multifaktorový priestor na kultivovanie vlastnej osobnosti, na sebarozvoj a zároveň na relaxovanie a prevenciu voči negatívnym dôsledkom náročného životného štýlu. Trávenie volného času sa významnou mierou podiel'a na well-beingu a na kvalite života umelcov. Opýtaní reflektovali pozitívne (80 \%), negatívne $(60 \%)$ i žiadne $(7,5 \%)$ vplyvy opatrení na trávenie vol’ného času. Viacerí sa vyjadrili, že pocitovali súčasne pozitívne aj negatívne zmeny.

\subsubsection{Pozitívne vplyvy opatrení na trávenie vol'ného času umelcov}

K najčastejšie spomínaným pozitívnym zmenám patrilo viac času na vlastné záujmy $(67,5 \%)$ a iné tvorivé aktivity $(17,5 \%)$ a častejšie trávenie času s rodinou $(27,5 \%)$. Tvorivé aktivity zahrnuli skladanie textov, cvičenie na hudobnom nástroji, mal’ovanie, výrobu dreveného nábytku atd’. Umelci vyzdvihovali aj nárast relaxačných aktivít (15\%). 
Tab. 8 Pozitívne vplyvy opatrení na trávenie vol'ného času respondentov; zdroj: vlastný.

\begin{tabular}{|c|c|c|}
\hline $\begin{array}{l}\text { Vplyvy } \\
\text { opatrení }\end{array}$ & \begin{tabular}{|l|} 
Počet \\
umelcov
\end{tabular} & Príklady vyjadrení \\
\hline $\begin{array}{l}\text { Viac času } \\
\text { na vlastné zá- } \\
\text { ujmy }\end{array}$ & $67,5 \%$ & $\begin{array}{l}\text { "Mala som viacej času pre seba..." } \\
\text { "Počas prvej vlny koronavírusu som trávil viac času na záhrade, priučil } \\
\text { som sa manuálnym a murárskym prácam. Našiel som zál'ubu v rezbár- } \\
\text { stve a vyrábal som nábytok z dreva." }\end{array}$ \\
\hline $\begin{array}{l}\text { Trávenie času } \\
\text { s rodinou }\end{array}$ & $27,5 \%$ & $\begin{array}{l}\text { "No prvá vlna bola super na usporiadanie rodinného života, nakol'ko som } \\
\text { (dovtedy) bol málo s det'mi a manželkou..." } \\
\text { "... celá rodina mohla pracovat'z domu, takže sme spolu trávili vel'a času..." }\end{array}$ \\
\hline $\begin{array}{l}\text { Realizácia tvo- } \\
\text { rivých aktivít }\end{array}$ & $17,5 \%$ & $\begin{array}{l}\text { "Začala som paradoxne viac tvorit'v oblasti hudby; skladanie textov a aj } \\
\text { medzinárodná spolupráca v oblasti hudby." }\end{array}$ \\
\hline Relaxovanie & $15 \%$ & $\begin{array}{l}\text { "Myslím, že sa udiali pozitívne zmeny. Našla som si režim, pokoj, zdravo } \\
\text { sa stravujem, mal'ujem, športujem a viac času trávim s rodinou..." } \\
\text { "Každý deň som trávil určitý čas prechádzkami a pohybom na čerstvom } \\
\text { vzduchu. " }\end{array}$ \\
\hline
\end{tabular}

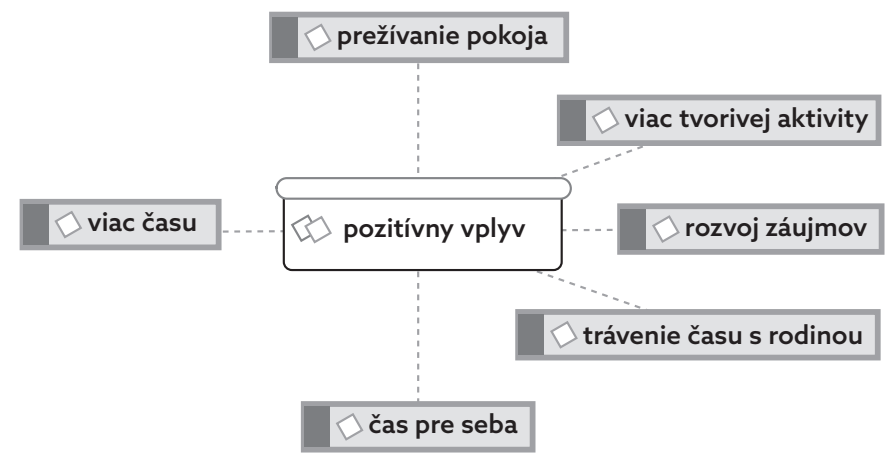

Obr. 4 Pozitívne vplyvy protipandemických opatrení na trávenie vol'ného času umelcov;

$$
\text { zdroj: vlastný. }
$$

Výrazný podiel na trávení vol’ného času umelcov mali záujmové aktivity. Identifikovali sme telovýchovné a športové, pracovno-technické a esteticko-výchovné záujmy. Najviac opýtaných sa venovalo športovým a turistickým záujmom $(32,5 \%$ ), druhou najčastejšie sa opakujúcou skupinou boli pracovno-technické záujmy, najmä práca v záhrade, ale aj šitie, pečenie chleba, práce spojené s úpravou prostredia a pod. (17,5\%). Najmenej zastúpená bola skupina spoločensko-vedných záujmov reprezentovaných pozeraním televízie (filmy, inscenácie a pod.) a čítaním kníh (15\%).

Uspokojovanie kultúrno-umeleckých a esteticko-výchovných záujmov bolo do značnej miery obmedzené, čo umelci komentovali medzi negatívnymi dôsledkami prijatých opatrení. 


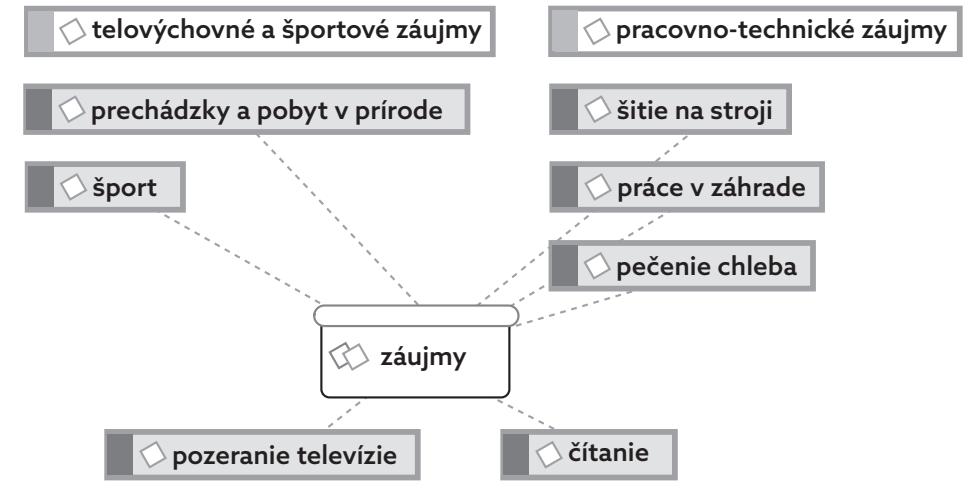

Obr. 5 Záujmy umelcov v čase pandémie; zdroj: vlastný.

Tab. 9 Záujmy respondentov počas pandémie; zdroj: vlastný.

\begin{tabular}{|l|l|l|}
\hline $\begin{array}{l}\text { Záujmy } \\
\text { umelcov }\end{array}$ & $\begin{array}{l}\text { Počet } \\
\text { umelcov }\end{array}$ & Príklady vyjadrení \\
\hline $\begin{array}{l}\text { Športové } \\
\text { záujmy }\end{array}$ & $32,5 \%$ & $\begin{array}{l}\text { "O tréningy atletiky, kalisteniky, boxu, fitness som neprišiel..." } \\
\text { "Čas som využíval najmä na šport." } \\
\text { "Ovel'a viac času som trávila vonku, v prírode. Kúpila som si horský } \\
\text { bicykel a najazdila } 1050 \mathrm{~km} \text { :)" }\end{array}$ \\
\hline $\begin{array}{l}\text { Pracovno-tech- } \\
\text { nické záujmy }\end{array}$ & $17,5 \%$ & $\begin{array}{l}\text { "Mala som viac času na prácu v rodinnom dome (prerábanie, práca } \\
\text { na záhrade...)." } \\
\text { "... poobede som pracoval v záhrade, v sade - oprava plotov, kydanie } \\
\text { hnoja z ovčína, strihanie stromov, sadenie, siatie, kosenie..." } \\
\text { "Oprášila som aj svoje staré zručnosti - šitie na šijacom stroji... ušila som } \\
\text { ich (rúšok) hned'niekol'ko. Pre seba, aj pre priatelov." }\end{array}$ \\
\hline $\begin{array}{l}\text { Spoločen- } \\
\text { sko-vedné } \\
\text { záujmy }\end{array}$ & $15 \%$ & $\begin{array}{l}\text { "... K pozeraniu filmov pribudlo aj pozeranie novších, či starších záz- } \\
\text { namov divadelných a televíznych inscenácií." }\end{array}$ \\
\hline
\end{tabular}

\subsubsection{Negatívne vplyvy opatrení na trávenie vol'ného času umelcov}

K negatívnym zmenám patrilo limitovanie cestovania $(17,5 \%)$, obmedzenie socializačných aktivít a možností kultúrneho vyžitia (15\%).

Až 20 \% respondentov paradoxne zaznamenalo medzi negatívnymi dôsledkami opatrení menej vol’ného času, čo pripisovali plneniu rodičovských povinností (napríklad suplovaniu úlohy učitel’a pri vzdelávaní vlastných detí), zvýšeniu nárokov na pracovné aktivity v rámci home office, či zmenám v dynamike správania (lenivost’, nechut'). 
Tab. 10 Negatívne vplyvy opatrení na trávenie vol'ného času respondentov; zdroj: vlastný.

\begin{tabular}{|l|l|l|}
\hline $\begin{array}{l}\text { Vplyvy } \\
\text { opatrení }\end{array}$ & $\begin{array}{l}\text { Počet } \\
\text { umelcov }\end{array}$ & Príklady vyjadrení \\
\hline $\begin{array}{l}\text { Limitovanie } \\
\text { cestovania }\end{array}$ & $17,5 \%$ & $\begin{array}{l}\text { "Nemôžem sa stretávat's priatel'mi ako obvykle, chodit' na kultúrne podu- } \\
\text { jatia či cestovat." } \\
\text { "V podstate to bola dlhšia vynútená dovolenka s tým rozdielom, že som } \\
\text { nikam nemohla cestovat'... Začala som skladat'puzzle :)" }\end{array}$ \\
\hline $\begin{array}{l}\text { Menej vol'ného } \\
\text { času }\end{array}$ & $20 \%$ & $\begin{array}{l}\text { "Bola som neustále s det'mi; čo sa týka vol'ného času, tak mám pocit, že ho } \\
\text { bolo ovel'a menej ako pred vypuknutím pandémie..." }\end{array}$ \\
\hline $\begin{array}{l}\text { Obmedzenie } \\
\text { socializačných } \\
\text { aktivít }\end{array}$ & $15 \%$ & $\begin{array}{l}\text { "Nemôžem sa stretávat's priatel'mi ako obvykle, chodit' na kultúrne podu- } \\
\text { jatia či cestovat.." } \\
\text { "Som vášnivá milovníčka cestovania, takže nemožnost'cestovat'pocitujem } \\
\text { ako dost' značné obmedzenie, chýba mi chodit' do divadla, na koncerty, } \\
\text { do galérie.... }\end{array}$ \\
\hline
\end{tabular}

Na záver nás zaujímalo, či umelci plánujú nejaké zmeny vo svojej pracovnej aktivite v súvislosti s obmedzením svojich umeleckých aktivít. Až 77,5\% jednoznačne odpovedalo, že nie, $10 \%$ vyjadrilo tendenciu v súčasnej práci „zatial““ zotrvat (ak to situácia dovolí) a len 12,5 \% sa vyjadrilo, že sú ochotní prácu zmenit za účelom zabezpečenia si stabilného príjmu.

\section{Diskusia}

Súčastou protipandemických opatrení je obmedzenie stretávania sa, zatvorenie divadiel, koncertných sál a zrušenie všetkých aktivít v oblasti umelecko-kreatívneho priemyslu, čo ovplyvňuje prácu umelcov, nakol'ko je závislá na priamom kontakte s obecenstvom. Ked’že dosah týchto opatrení na umelcov na Slovensku nie je preskúmaný, rozhodli sme sa zrealizovat výskumnú sondu na vzorke tých umelcov, ktorí si dopíñajú pedagogické vzdelanie na Akadémii umení v Banskej Bystrici.

Rovnako ako v zahraničí, aj na slovenskej umeleckej scéne sa realizovali rôzne online aktivity, prevažne streamovanie koncertov, predstavení a vystúpení (často z domáceho prostredia, z námestí a sídlisk), prvá online premiéra v histórii nášho divadla, či vytvorenie, resp. zdielanie programov s hudobným i dramatickým obsahom na stránkach významných kultúrnych inštitúcií. Aktivity slovenských umelcov sú v súlade s tvrdením, že hudobníci v Európe a v Amerike začali propagovat domáce koncerty na platformách ako YouTube a Facebook ${ }^{14}$. Aj napriek snahe pokračovat' v umeleckej činnosti, pandémia ovplyvnila život mnohých umelcov, čo sme zistovali výskumnou sondou.

V našej vzorke bolo za najzávažnejší dôsledok pandémie považované zníženie príjmov. Okrem umeleckého príjmu sme u respondentov zaznamenali aj príjem z inej činnosti (pedagogicko-umeleckej, umeleckej aj mimoumeleckej). Zistili sme, že doplňujúce umelecké aktivity zahŕňajú predovšetkým prácu hercov a v hudobných pozíciách ide

14 BIENVENU, Grégoire. Is livestreaming the post-Covid-19 future for live music? 2020, s. 5. 
v podstate len o prácu hudobného redaktora. Možno usudzovat', že herci sa dokážu zamestnat’ v rôznych umeleckých pozíciách, kým hudobníci predovšetkým vyučujú alebo si hladajú doplňujúci zdroj príjmov v mimoumeleckých oblastiach. (Hoci nevylučujeme možnosț „privyrábania“ si hercov v mimoumeleckej oblasti, považujeme ju za menej frekventovanú ako u hudobníkov.) Dôvodom by mohla byt̉ menšia variabilita v umeleckom uplatnení v oblasti hudobného umenia v porovnaní s dramatickým umením.

Väčšina respondentov zaevidovala výpadok alebo zníženie príjmu z umeleckej činnosti. Na rozdiel od USA, kde 27,4 \% umelcov ostalo nezamestnaných ${ }^{15}$, v našej vzorke boli všetci umelci zamestnaní (nie len v umelecko-kreatívnom priemysle) a tri štvrtiny z nich neuvažovali o zmene povolania. Vd’aka rôznym pracovným aktivitám mohli respondenti udržat' svoj životný štandard na približne nezmenenej úrovni. Toto zistenie podporuje názor H. Abbinga, ktorý už v časoch pred pandémiou tvrdil, že v západných krajinách Európy by si väčšina umelcov nevedela zabezpečit živobytie len z umeleckej činnosti ${ }^{16}$.

V psychickej oblasti sme zaznamenali len negatívne dôsledky (hoci sme neformulovali žiadnu otázku zameranú na psychické dôsledky, sami umelci sa spontánne vyjadrovali aj k tejto téme). I ked' podla niektorých výskumov ${ }^{17}$ sa hudobníci (študenti) v procese učenia sa počas pandémie koncentrujú na svoje výkony (pedagóga by sme mohli považovat za ekvivalent diváka - ako „spotrebitela umenia“ profesionálov), viacerí respondenti pocitovali stratu motivácie. Okrem nej spomínali obavy a neistotu. Aj napriek predikciám, že koncertné sály a orchestre postupne ožijú a spev sa vráti do kostolov, na koncertné a divadelné pódiá ${ }^{18}$, ukázalo sa, že po krátkom čase uvol’nenia sa s nástupom druhej vlny pandémie situácia zopakovala, čo aj nad’alej stimuluje nárast neistoty v dôsledku ohrozenia základných životných potrieb umelcov participujúcich na výskume.

V zmysle trávenia vol’ného času sme zistili, že umelci hodnotili obdobie opatrení prevažne pozitívne. Zmena ich pracovného tempa a spôsobu vykonávania pracovných aktivít sa odzrkadlila aj v zmene trávenia vol'ného času, ktorý začali venovat viac sebe a svojej rodine (čo považujeme za logický dôsledok obmedzenia pracovných aktivít). Tendenciu trávit vol'ný čas najmä pohybovými aktivitami a pracovnými činnostami prisudzujeme nedostatočnému, resp. repetitívnemu pohybu umelcov počas štandardnej pracovnej zátaže a následným tažkostiam najmä s muskuloskeletálnym systémom, ktorých existenciu u hudobníkov dokumentuje kvantum výskumov ${ }^{19}$, ako aj snahe kompenzovat nakumulované emočné napätie fyzickou aktivitou.

15 MARRONE, James V., RESETAR, Susan A., SCHWAM, Daniel. 2020. The Pandemic Is a Disaster for Artists [online]. 2020, 4. august. [cit. 2020-11-05]. Dostupné z: https://www.rand.org/blog/2020/07/the-pandemicis-a-disaster-for-artists.html.

16 ABBING, Hans. The Value for Artists of Work and Money. 2010, s. 2.

17 PHILIPPE, Roberta Antonini, SCHIAVIO, Andrea, BIASUTTI, Michele. 2020. Adaptation and destabilization of interpersonal relationships in sport andmusic during the Covid-19 lockdown. 2020, s. 5.

18 BOTSTEIN, Leon. The Future of Music in America: The Challenge of the COVID-19 Pandemic. 2020. s. 353.

19 Napr. CRUDER, FALLA, MANGILI et al. Profiling the Location and Extent of Musicians' Pain Using Digital Pain Drawings. 2017, s. 1. 


\section{Záver}

„Ušlý zisk je zanedbatelnýv vorounani s tým, že som nemohol robit to, čo bytostne potrebujem. “ (umelec - doktorand, pedagóg)

Umelecký svet čelí v dôsledku prísnych opakujúcich sa protipandemických opatrení velkej výzve. Obmedzenie zhromažd’ovania, sociálny dištanc a dodržiavanie hygienických opatrení spôsobili, že práca umelcov ako sprostredkovatelov umeleckých zážitkov percipientovi umenia prostredníctvom živého kontaktu je ohrozená. V určitých časových obdobiach boli (a momentálne opät sú) zrušené všetky hromadné spoločenské a kultúrne podujatia, čo sa prejavilo na znížených alebo úplne absentujúcich príjmoch v oblasti divadelného, tanečného i hudobného umenia. Vo výskumnej sonde sme sledovali vplyv protipandemických opatrení na život umelcov v oblasti hudobného a divadelného umenia, frekventantov Doplňujúceho pedagogického štúdia na Akadémii umení v Banskej Bystrici, na ich pracovné aktivity, trávenie volného času a psychiku. Zistili sme, že väčšina umelcov pocítila výrazné reštrikcie v pracovných aktivitách, no v mnohých prípadoch boli umelci schopní bez velkých zmien vo výdavkoch prekonat negatívne zmeny v príjmoch. Najčastejšími formami prekonania tažkostí boli: práca v oblasti školstva (kedže sa platy učitelov väčšinou neznižovali), fungovanie domácnosti z finančných rezerv, či presun financovania domácnosti na partnera/manžela. Takéto riešenie situácie však umelci považujú len za dočasné, nakolko chýbajúce príjmy nie sú schopní uvedenými formami dlhodobo suplovat'. Niektorí umelci začali v dôsledku protipandemických opatrení šetrił a v jednom prípade museli členovia dotknutej domácnosti prijat výrazné opatrenia.

Po psychickej stránke sme u umelcov zaznamenali viaceré negatívne zmeny. Išlo predovšetkým o prežívanie neistoty, frustrácie a straty motivácie k dalšiemu sebarozvoju. Umelci pocitovali aj sklamanie vyplývajúce $\mathrm{z}$ blokovania možnosti prezentovat vlastný potenciál pred živým publikom a psychický tlak (bližšie nešpecifikovaný).

Z hladiska trávenia volného času väčšina umelcov zaznamenala $\mathrm{v}$ čase pandémie pozitívne zmeny. Okrem telovýchovných, pracovno-technických a esteticko-výchovných záujmov sa respondenti venovali sebarozvoju, tráveniu času s rodinami a relaxovaniu. Niektorí vyjadrili nespokojnost’ so skrátením času určeného na vol’nočasové aktivity, pričom príčiny pripisovali zvýšeniu náročnosti práce v home office a starostlivosti o členov rodiny (učenie sa s detmi). Najviac negatívnych vyjadrení v uvedenej súvislosti sa týkalo obmedzenia cestovania, kultúrno-spoločenských akcií a iných socializačných aktivít.

Napriek všetkým tažkostiam sa viac ako tri štvrtiny opýtaných umelcov vyjadrili, že žiadne zmeny vo svojej pracovnej sfére neplánujú a neuvažujú o zmene povolania, ak im situácia dovolí d’alej pôsobit v oblasti umenia.

Pozn. autorov: príspevok vznikol v čase zákazu vychádzania a celoplošného testovania na COVID-19 na Slovensku. 


\section{Bibliography}

ABBING, Hans. The Value for Artists of Work and Money. [online]. In the16-th International conference on cultural Economics in Copenhagen. 2010, jún. [cit. 2020-10-15]. Dostupné z: https:// scholar.google.com/scholar?cluster $=13868296981068119998 \&$ chl=sk\&as_sdt $=0,5 \&$ sciodt $=0,5$.

BIENVENU, Grégoire. Is livestreaming the post-Covid-19 future for live music? [online]. 2020, máj. [cit. 2020-11-08]. Dostupné z: https://www.researchgate.net/publication/342360942_Is_livestreaming_the_post-Covid-19_future_for_live_music.

BOTSTEIN, Leon. The Future of Music in America: The Challenge of the COVID-19 Pandemic. [online]. The Musical Quarterly, 2020, roč. 102, číslo 4, s. 351-360, [cit. 2020-11-05]. Dostupné z: https://doi.org/10.1093/musqtl/gdaa007.

CRUDER, Cinzia, FALLA, Deborah, MANGILI, Francesca et al. Profiling the Location and Extent of Musicians' Pain Using Digital Pain Drawings. [online]. Pain Practice, 2017, roč. 18, č. 1, [cit. 2020-11-05]. Dostupné z: https://www.researchgate.net/publication/316652238_Profiling_ the_Location_and_Extent_of_Musicians__Pain_Using_Digital_Pain_Drawings.

MARRONE, James V., RESETAR, Susan A., SCHWAM, Daniel. The Pandemic Is a Disaster for Artists. [online]. 2020, 4. august. [cit. 2020-11-05]. Dostupné z: https://www.rand.org/blog/2020/07/ the-pandemic-is-a-disaster-for-artists.html.

PHILIPPE, Roberta Antonini, SCHIAVIO, Andrea, BIASUTTI, Michele. 2020. Adaptation and destabilization of interpersonal relationships in sport and music during the Covid-19 lockdown. [online]. Heliyon, roč. 6, číslo 10, e05212. [cit. 2020-11-05]. Dostupné z: https://doi. org/10.1016/j.heliyon.2020.e05212.

Uznesenie vlády Slovenskej republiky č. 678 z 22.10.2020. [online]. Bratislava: Ministerstvo investícií, regionálneho rozvoja a informatizácie SR. [cit. 2020-10-20]. Dostupné z: https://korona.gov.sk/ wp-content/uploads/2020/10/zakaz-vychadzania-678_2020.pdf.

Opatrenia Úradu verejného zdravotníctva SR pri ohrozeni verejného zdravia:

OLP/4085/2020. [online]. 19.05.2020. Bratislava: ÚVZ SR. [cit. 2020-11-05]. Dostupné z: https:// www.uvzsr.sk/docs/info/covid19/19_05_2020_Opatrenie_hromadne_podujatia.pdf.

OLP/4592/2020. [online]. 02.06.2020. Bratislava: ÚVZ SR. [cit. 2020-10-05]. Dostupné z: https:// www.uvzsr.sk/docs/info/covid19/final_opatrenie_prevadzky_4_faza_02_06.pdf.

OLP/4738/2020. [online]. 09.06.2020. Bratislava: ÚVZ SR. [cit. 2020-10-12]. Dostupné z: https:// www.uvzsr.sk/docs/info/covid19/Opatrenie_UVZSR_prevadzky_09062020.pdf.

OLP/5091/2020. [online]. 19.06.2020. Bratislava: ÚVZ SR. [cit. 2020-10-12]. Dostupné z: https:// www.uvzsr.sk/docs/info/covid19/19_06_final_opatrenia_prevadzky_a_HP.pdf.

OLP/5274/2020. [online]. 25. 06. 2020. Bratislava: ÚVZ SR. [cit. 2020-10-12]. Dostupné z: https://www.uvzsr.sk/docs/info/covid19/Opatrenie_UVZSR_pri_ohrozeni_verejneho_zdravia_25.06.2020_prevadzky.pdf.

OLP/5454/2020. [online]. 03.07.2020. Bratislava: ÚVZ SR. [cit. 2020-10-12]. Dostupné z: https://www.uvzsr.sk/docs/info/covid19/Opatrenie_UVZSR_zmena_opatrenia_prevadzky_a_ HP_03072020.pdf.

OLP/8326/2020. [online]. 14.10.2020. Bratislava: ÚVZ SR. [cit. 2020-10-10]. Dostupné z: https:// www.uvzsr.sk/docs/info/covid19/final_opatrenie_prevadzky_a_HP_15_10.pdf.

OLP/7311/2020. [online]. 17.09.2020. Bratislava: ÚVZ SR. [cit. 2020-10-10]. Dostupné z: https:// www.uvzsr.sk/docs/info/covid19/final_navrh_opatrenie_prevadzky_a_HP_16_09.pdf. 
OLP/8326/2020. [online]. 14.10.2020. Bratislava: ÚVZ SR. [cit. 2020-10-12]. Dostupné z: https:// www.uvzsr.sk/docs/info/covid19/final_opatrenie_prevadzky_a_HP_15_10.pdf. 
